\title{
Anemia with Spur Cells: a Red Cell Defect Acquired in Serum and Modified in the Circulation
}

\author{
R. A. COOPER \\ From the Thorndike Memorial Laboratory and 2nd and 4th (Harvard) \\ Medical Services, Boston City Hospital, and the Department of Medicine, \\ Harvard Medical School, Boston, Massachusetts 02118
}

A в S T R A C T The sera and red cells of three patients with severe liver disease and "spur cells" were studied. In each case the per cent of serum cholesterol which was free (unesterified) was elevated, and the serum lecithin: cholesterol acyltransferase activity was depressed. Lipoproteins with beta mobility were increased, but exhibited immune reactivity with antisera to both alpha- and beta-lipoproteins. Serum bile salt concentrations were markedly elevated and consisted primarily of chenodeoxycholic acid, with small amounts of lithocholic acid present as well.

Spur cells manifested a striking increase in cholesterol content and in the cholesterol: phospholipid ratio, but a normal osmotic fragility. When incubated in heated normal serum, spur cells lost their excess cholesterol and became spherocytic and osmotically fragile. Conversely, sera from patients with spur cells readily transferred up to one-third of their free cholesterol to normal red cells, causing normal cells to become resistant to osmotic lysis. In addition, these sera caused normal red cells to acquire thorny membrane projections. Cholesterol transfer to normal cells also occurred from normal serum which had previously been incubated with spur cells. Changes in cell cholesterol were induced by all of the lipoprotein fractions of spur serum.

When transfused into a patient with spur cells, normal red cells became more resistant to osmotic lysis over the course of $24 \mathrm{hr}$. However, over the subsequent 7 days they underwent a progressive increase in osmotic fragility. These normal cells, as well as the patient's own cells, had a shortened survival. Correlating with the moderate decrease in the filterability of red cells spurred in vitro, red cell destruction occurred predominently in the spleen.

A portion of this work was previously reported in abstract form (1).

Received for publication 20 March 1969 and in revised form 10 June 1969.
Red cells in this disorder appear to serve as repositories for free cholesterol loosely bound to serum lipoproteins. Cholesterol acquisition by the red cell membrane increases its surface area and causes the red cell to be resistant to osmotic lysis. The associated alteration in red cell shape leads to further changes in the cell membrane during circulation in vivo resulting in the loss of membrane surface area and culminating in the cell's premature destruction in the spleen.

\section{INTRODUCTION}

Over the past $5 \mathrm{yr}$, a small number of patients have been reported with the syndrome of hemolytic anemia and red cells resembling acanthocytes in association with severe liver disease (2-8). The term "spur cell" has been applied to these bizarre red cells (2), and it serves both to describe their unusual thorny projections and to distinguish them from the morphologically similar but chemically dissimilar acanthocytes seen in patients with abetalipoproteinemia $(9,10)$. With the exception of two patients with neonatal hepatitis (7), the patients reported with spur cells have been adults with alcoholic liver disease. Their clinical features have included jaundice, hepatomegaly, splenomegaly, hemorrhagic diathesis, and hemolysis with sequestration of red cells in the spleen.

Evidence for the acquired nature of this red cell morphologic abnormality has been obtained in vitro by several investigators $(2,5,7)$, but has been denied by others $(3,4,6)$. However, in two studies normal red cells transfused into patients with spur cells became morphologically similar to the recipients' own cells $(2$. 3 ). The lipid content of spur cells has been measured in six of these patients and reported as increased in four $(2,6)$ but normal in the other two $(3,4)$.

This report describes studies of three patients with spur cells and a syndrome very similar to that reporter 
previously. The results of these studies support the concept that: $(a)$ red cells in this disorder serve as the repository for cholesterol loosely bound to serum lipoproteins; (b) that cholesterol accumulation in the membrane results in an increased surface area and osmotic resistance; (c) that concomitant with (but not necessarily due to) the acquisition of cholesterol membrane architecture is distorted; $(d)$ and that cells so distorted are limited in their ability to traverse small orifices causing them to undergo a loss of membrane surface area while circulating in vivo leading ultimately to their destruction in the spleen.

\section{METHODS}

Patients with spur cells. A summary of the clinical findings in the three patients with spur cells who were studied is presented in Table I. Patient 1 , the subject of most of these studies, was a $25 \mathrm{yr}$ old white male with a $10 \mathrm{yr}$ history of alcoholism. Investigations were performed over the course of $1 \mathrm{yr}$ while the patient abstained from alcohol after a severe episode of alcoholic hepatitis. Studies terminated when an upper gastrointestinal hemorrhage in the face of known esophageal varices led to a splenectomy and a splenorenal shunt. The patient died on his third postoperative day of intra-abdominal bleeding. Postmortem examination revealed a severely scarred and necrotic liver with scattered areas of regeneration. Patient 2 was a $56 \mathrm{yr}$ old white male with cirrhosis of the alcholic and ascites. He died of a massive gastrointestinal hemorrhage 4 months after being studied. Patient 3 was a 67 yr old white female who had a 2 yr history of cirrhosis of the alcoholic and ascites before study. She died 3 months after being studied.

Examination of red cells. Red cell morphology was assessed both in wet preparations and on Wright's stained smears. Osmotic fragility was carried out according to Emerson, Shen, Ham, Fleming, and Castle (11). The lipids of quadruplicate aliquots of red cells were extracted with isopropanol and chloroform (12) and freed of nonlipid phosphorus by thrice washing with $\frac{1}{5}$ volume of $0.05 \mathrm{M} \mathrm{KCl}$. Cholesterol (13) and lipid phosphorus (14) were measured with SE ( $95 \%$ confidence limits) of 1.8 and $2.4 \%$, respectively. The sterol composition of red cell extracts was assessed using two dimensional thin-layer chromatography (TLC) (15) and gas-liquid chromatography (GLC) (16). Red cell sterols were isolated by digitonin precipitation and GLC of the trimethylsilyl derivative was performed on an SE 30 column and of the trifluoroacetic acid derivative on a QF1 column. ${ }^{1}$ Ghosts were prepared from red cells using the method of Dodge, Mitchell, and Hanahan (17), and their lipids were analyzed using the procedure outlined for intact red cells. Red cell filterability was determined according to Jandl, Simmons, and Castle (18), using $5 \mu$ Millipore filters. Filtration was allowed to proceed for $15 \mathrm{~min}$ with a negative pressure of $20 \mathrm{~mm} \mathrm{Hg}$. The filterability of red cells after incubation was expressed as a per cent of the same red cell population suspended in normal heated serum which was able to traverse the filter before in -ubation. Red cells were enumerated in a Coulter Model B electronic counter (Coulter Electronics, Chicago, Ill.). Cellular $\mathrm{Na}$ and $\mathrm{K}$ were measured by flame photometry after the re-

\footnotetext{
${ }^{1}$ Gas-liquid chromatography was performed in collaboration with Dr. W. Admirand.
}

TABLE 1

Summary of Clinical Data

\begin{tabular}{lccc}
\hline & Patient 1 & Patient 2 & Patient 3 \\
\hline Hematocrit, \% & 20 & 28 & 16 \\
Reticulocytes, \% & 10.6 & 3.8 & 2.0 \\
Spur cells, \% & $25-85$ & $20-30$ & $30-50$ \\
Bilirubin, $m g / 100 m l$ & 18 & 5.5 & 12.0 \\
SGOT, $U$ & 125 & 134 & 58 \\
Albumin, g/100 ml & 4.0 & 2.3 & 3.6 \\
Prothrombin time/control, & & & \\
$\quad$ sec & $18.0 / 12.5$ & $18.4 / 11.4$ & $15.9 / 11.9$ \\
Spleen* & 10 & 2 & 2 \\
Liver* & 10 & 8 & 6 \\
\hline
\end{tabular}

SGOT = serum glutamic oxaloacetic transaminase.

* cm below costal margins.

moval of extracellular $\mathrm{Na}$ and $\mathrm{K}$ by washing rapidly with isotonic $\mathrm{MgCl}_{2}$.

Examination of serum. Sera were extracted with acetone : ethanol $(1: 1)$ at $50^{\circ} \mathrm{C}$ for measurement of total (13) and free cholesterol (19) and lipid phosphorus (14). Phospholipid values were taken to equal lipid phosphorus $\times 27$. Fractions of serum were obtained by ultracentrifugation for 36 $\mathrm{hr}(20)$. The serum density was adjusted with solid $\mathrm{KBr}$ and verified by pyknometry. Serum lipoproteins were separated electrophoretically in agarose (21) and examined after staining with Sudan black B. Immunoelectrophoresis was also performed in agarose (22) using commercial antisera. ${ }^{2}$ The trifluoroacetic acid derivatives of serum bile salts were measured on a QF1 column according to Sandberg, Sjövall. Sjövall, and Turner (23). ${ }^{1}$

Studies in vitro. Red cells obtained from defibrinated blood were washed free of white cells in Hank's balanced salt solution. Unless otherwise specified, $1.0 \mathrm{ml}$ of a $10 \%$ suspension of red cells in Hank's solution was incubated with $1.0 \mathrm{ml}$ of compatible serum containing penicillin, 1000 $\mathrm{U} / \mathrm{ml}$. Incubations were performed in stoppered, sterile, $16 \times 150 \mathrm{~mm}$ test tubes in a $37^{\circ} \mathrm{C}$ atmosphere shaking at 130 oscillations/min for 20-24 hr. During incubation under these conditions, $\mathrm{pH}$ varied from 7.2 to 7.5 . When red cells were incubated at a cell concentration greater than $10 \%$, glucose was added as $5 \%$ dextrose in water to raise the glucose concentration of the medium $100 \mathrm{mg} / 100 \mathrm{ml}$ for each $10 \%$ rise in cell concentration. Sera referred to as "heated" were heated to $56^{\circ} \mathrm{C}$ for $30 \mathrm{~min}$ to inactivate the serum enzyme. lecithin: cholesterol acyltransferase and prevent the esterification of free cholesterol during incubation $(24,25)$. The data in Table VIII were obtained using a single pool of acidcitrate-dextrose (ACD) plasma obtained from patient 1 by plasmapheresis and clotted with bovine thrombin. The osmotic fragility of red cells after incubation was determined by a modification (26) of the method of Emerson et al. (11). Normal platelets were harvested from blood anticoagulated with ACD by differential centrifugation and incubated in ACD plasma at a platelet concentration of $5 \times 10^{8} / \mathrm{ml}$ for $24 \mathrm{hr}$ at $37^{\circ} \mathrm{C}$. Normal subjects who served as donors of red cells, platelets, and serum were laboratory personnel or patients without manifestations of either hepatiz of hematologic disease.

${ }^{2}$ Antisera were obtained from Behringwerke. 
TABLE II

Serum and Red Cell Lipids

\begin{tabular}{|c|c|c|c|c|c|}
\hline & Patient 1 & Patient 2 & Patient 3 & Normals & $\pm 2 \mathrm{SD}$ \\
\hline Cholesterol, $\mu \mathrm{g} / 10^{8}$ cells & 22.52 & 19.50 & 19.11 & 13.41 & \pm 1.44 \\
\hline Lipid phosphorus, $\mu \mathrm{g} / 10^{8} \mathrm{cells}$ & 1.235 & 1.369 & 1.275 & 1.264 & \pm 0.072 \\
\hline Cholesterol :lipid phosphorus & 18.23 & 14.35 & 15.56 & 10.60 & \pm 1.12 \\
\hline \multicolumn{6}{|l|}{ Serum } \\
\hline Total cholesterol, $m g / 100 \mathrm{ml}$ & 417.0 & 132.0 & 347.2 & 184.9 & \pm 70.4 \\
\hline Free cholestercl, $m g / 100 m l$ & 216.0 & 58.1 & 180.8 & 45.9 & \pm 13.2 \\
\hline Free cholesterol, \% of total & 51.7 & 44.0 & 52.1 & 26.8 & \pm 9.6 \\
\hline Phespholipid, $\mathrm{mg} / 100 \mathrm{ml}$ & 332.5 & 179.8 & 372.1 & 256.4 & \pm 120.0 \\
\hline
\end{tabular}

Studies in vivo. The survival and sites of organ sequestration of red cells labeled with $\mathrm{Na}_{2}^{51} \mathrm{CrO}_{4}$ were determined by the method of Jandl, Greenberg, Yonemoto and Castle (27). Compatibility between the normal red cell donor and spur cell recipient was determined by the Coombs crossmatching procedure (28). The osmotic fragility of ${ }^{51} \mathrm{Cr}$ labeled red cells after transfusion was determined as described previously $(26,29)$. Patient 1 , who served as the recipient of ${ }^{81} \mathrm{Cr}$-labeled red cells, was apprised of the experimental details and gave his free consent. The protocol for this study was approved by the Review Committee, Thorndike Memorial Laboratory.

\section{RESULTS}

Red cell lipids. The lipid content of red cells from three patients with spur cells and from eleven normal subjects is shown in Table II. The cholesterol content of red cells from all three patients was markedly increased and averaged $52 \%$ greater than normal. The cholesterol and phospholipid content of ghosts prepared from the red cells of patient 1 was identical to that of the intact cells, indicating that this additional cholesterol was located in the cell membrane. Using a system of two dimensional thin-layer chromatography (15), the sterol contained in the lipid extract of red cells of patient 1 could not be differentiated from the cholesterol standard.

Serum lipids. The serum lipid values from the three patients with spur cells are presented in Table II. The serum levels of both cholesterol and phospholipid were elevated in two patients but were in the normal range in the third. In all three patients, however, free cholesterol represented a greater than normal per cent of the total serum cholesterol.

When serum is incubated in vitro at $37^{\circ} \mathrm{C}$, free cholesterol normally becomes esterified due to the heat-labile serum enzyme, lecithin: cholesterol acyltransferase (24, $25)$. The activity of this enzyme in 12 normal subjects resulted in the esterification of $18-30 \mathrm{mg}$ of free cholesterol/100 $\mathrm{ml}$ of serum during incubation for $24 \mathrm{hr}$. This enzyme activity was absent in the serum from patient 1 and was decreased in sera from the other two patients, resulting in the esterification of $6.8 \mathrm{mg}$ of free cholesterol $/ 100 \mathrm{ml}$ of serum in patient 2 and 13.4 $\mathrm{mg}$ in patient 3 .

The relative quantities of alpha- and beta-lipoprotein were estimated from electrophoretic separations of serum in agarose (21). The amount of lipid staining material in the beta globulin band was increased in all three patients. However, in each case this band exhibited immune reactivity with antiserum to both alpha- and betalipoprotein. The amount of lipid-staining material migrating with the alpha globulins was normal in patients 1 and 3 but slightly decreased in patient 2 ; it reacted only with antiserum to alpha-lipoprotein.

Serum bile salts. Bile salt concentrations were markedly elevated in the sera of all three patients and consisted primarily of chenodeoxycholic acid (Table III). Lithocholic acid, normally undetectable in serum or present in very small amounts $(30)$, was readily detected in all three patients.

The effect of spur cell serum on normal red cells. After incubation in spur sera, ${ }^{3}$ normal red cells had an increased content of cholesterol, but they retained their normal content of phospholipid (Table IV). In addition, these red cells were more resistant to osmotic lysis. However, they underwent no changes in mean cell volume or in the cellular concentrations of hemoglobin, $\mathrm{Na}$, or $\mathrm{K}$. Moreover, parallel incubations of these normal red cells in heated normal sera resulted in no change in either their lipid content or osmotic fragility. Thus, the increased resistance to osmotic lysis observed in normal red cells after incubation in sera from patients with spur cells reflected an increase in cell surface area.

During incubations in sera from all three spur cell patients, normal red cells acquired thorny membrane projections, while in heated autologous sera they main-

\footnotetext{
${ }^{3}$ For brevity, the term "spur sera" will be used to refer to sera from patients with spur red cells.
} 
tained their normal discoidal shape. The relationship between the morphologic alterations observed in vitro and the accompanying changes in membrane cholesterol and surface area is shown in Fig. 1, which represents the time course of these changes during the incubation of normal red cells in the serum from patient 1 . There was a progressive increase in the red cell content of cholesterol with time, and this closely paralleled the progressive increase in resistance to osmotic lysis. Although no causal relationship is implied, the degree of morphologic change observed on Wright's stained smears correlated with the observed changes in cholesterol content and osmotic fragility. Similar morphologic changes were seen in wet preparations viewed on plastic slides after incubation in plastic vessels.

To test whether these changes were reversible, normal red cells were first incubated in serum from patient 1 for $24 \mathrm{hr}$ and then incubated for a second $24 \mathrm{hr}$ in heated normal serum. During the first $24 \mathrm{hr}$ they acquired a $64 \%$ increment in cholesterol and underwent the morphologic changes shown in Fig. 1. After the second $24 \mathrm{hr}$ period of incubation, the red cell content of cholesterol was normal and the thorny membrane projections were no longer present. Their biconcave nature at the end of this second period of incubation was emphasized by the ease with which they formed rouleaux. There was no change in either the cholesterol content or morphology of normal cells incubated simultaneously in normal heated serum for the entire $48 \mathrm{hr}$.

When normal red cells were incubated in various quantities of serum from patient 1 (brought to a constant volume with Hank's solution), the amount of cholesterol acquired by these cells increased as the ratio of serum volume to packed cell volume was increased (Fig. 2). A maximum increment in red cell cholesterol was attained when the ratio of serum volume to cell volume was $3: 1$. The transfer of cholesterol to normal red cells at each of these serum dilutions was not enhanced by the addition of sodium taurocholate at a concentration of $1.0 \mathrm{mg} / \mathrm{ml}$ of serum. The sterol present in normal red cells after incubation in serum from patient 1 was entirely digitonin precipitable, and gas-

TABLE III

Serum Bile Acids

\begin{tabular}{|c|c|c|c|c|}
\hline & $\begin{array}{c}\text { Patient } \\
1\end{array}$ & $\begin{array}{c}\text { Patient } \\
2\end{array}$ & $\begin{array}{c}\text { Patient } \\
3\end{array}$ & $\begin{array}{l}\text { Normal } \\
\text { range* }\end{array}$ \\
\hline Total bile acids, $\mu g / m l$ & 196.5 & 26.3 .2 & 174.3 & $0.13-2.26$ \\
\hline Cholic acid, $\mu g / m l$ & 8.1 & 24.8 & 7.3 & $0.03-0.60$ \\
\hline Deoxycholic acid, $\mu g / m l$ & 1.1 & 0.6 & 0.9 & $0.05-1.30$ \\
\hline Chenodeoxycholic acid, $\mu \mathrm{g} / \mathrm{ml}$ & 181.4 & 235.4 & 165.4 & $0.06-0.45$ \\
\hline Lithocholic acid, $\mu \mathrm{g} / \mathrm{ml}$ & 5.9 & 2.4 & 0.7 & $\stackrel{+}{+}$ \\
\hline
\end{tabular}

* Normal values obtained from Sandberg et al. (23).

+ Present in amounts not normally measurable by this method.
TABLE IV

Effect of Patients' Serum on the Lipid Content and Osmotic Fragility of Normal Red Cells

\begin{tabular}{lccc}
\hline & $\begin{array}{c}\text { Choles- } \\
\text { terol }\end{array}$ & $\begin{array}{c}\text { Lipid } \\
\text { Phosphorus }\end{array}$ & $\begin{array}{c}\text { Mean } \\
\text { osmotic } \\
\text { fragility } \\
\mathrm{NaCl}\end{array}$ \\
\cline { 2 - 4 } & $\begin{array}{c}\mu \mathrm{g} / 10^{8} \\
\text { cells }\end{array}$ & $\begin{array}{c}\mu g / 10^{\circ} \\
\text { cells }\end{array}$ & $\mathrm{g} / 100 \mathrm{ml}$ \\
& 13.64 & 1.270 & 0.421 \\
Initial values* & & & \\
After incubation in : & 23.80 & 1.302 & 0.308 \\
Serum from patient 1 & 17.05 & 1.312 & 0.405 \\
Serum from patient 2 & 17.96 & 1.288 & 0.358 \\
Serum from patient 3 & 13.61 & 1.262 & 0.427 \\
Normal heated serum* & & & \\
\hline
\end{tabular}

* Values are averaged from three separate experiments in each of which the serum of one patient was evaluated. Red cells for all three experiments wert from a single normal donor.

liquid chromatography failed to distinguish it from cholesterol. To assess cholesterol transfer in serum from patients 2 and 3 , normal red cells were incubated at serum: cell ratios of $10: 1$ and $1: 1$ (Fig. 2). There was less cholesterol gained by red cells in sera from patients 2 and 3 than in serum from patient 1 at both ratios, despite the fact that the serum concentration of cholesterol was similar in patients 1 and 3 . Thus, the serum cholesterol concentration does not predict the affinity with which this cholesterol is held by serum lipoproteins.

To test whether the effects seen in Fig. 2 were due to serum dilution alone rather than to changes in the se-

TABLE V

Effect of Sequential Incubations with Normal Red Cells on the Free Cholesterol Concentration of Spur Cell Serum*

\begin{tabular}{lrrrr}
\hline & \multicolumn{5}{c}{ Serum free cholesterol } \\
\cline { 2 - 5 } \multicolumn{1}{c}{ Incubation } & Exp. 1 & Exp. 2 & Mean & Decrease. \\
\cline { 2 - 5 } & \multicolumn{5}{c}{$m g / 100 m l$} & $\%$ \\
Before incubation & 196 & 175 & 186 & - \\
After first incubation & 143 & 147 & 145 & 22 \\
After second incubation & 124 & 119 & 122 & 12 \\
After third incubation & 120 & 109 & 114 & 4
\end{tabular}

* $1 \mathrm{ml}$ of serum from patient 1 was incubated with $1.0 \mathrm{ml}$ of a $50 \%$ suspension of red cells in Hank's solution for $12 \mathrm{hr} .1 \mathrm{ml}$ of the supernatant of this incubation was incubated with a second aliquot of normal red cells in Hank's solution and this was repeated a third time. The concentration of free cholesterol in serum was obtained from a measurement of its concentration in the supernatant and a calculation to adjust for the dilution of serum with Hank's solution. There was a decrease in the serum concentration of free cholesterol which was greatest during the first incubation and which, after 3 incubations, accounted for $38 \%$ of the initial free cholesterol concentration. 
rum: cell ratio, normal red cells were incubated in serum from patient 1 at a serum: cell ratio of $10: 1$, and the entire cell suspension was diluted with either one or two volumes of buffer to give final cell concentrations of 5 and $2.5 \%$. There was a similar increase in the red cell content of cholesterol at each of these dilutions.
Thus, serum dilution does not appear to influence the serum-cell transfer of cholesterol.

In an effort to isolate by flotation a fraction of spur serum which could account for the transfer of cholesterol from serum to cells, serum from patient 1 was separated into six density fractions : $<1.006,1.006-1.012$.
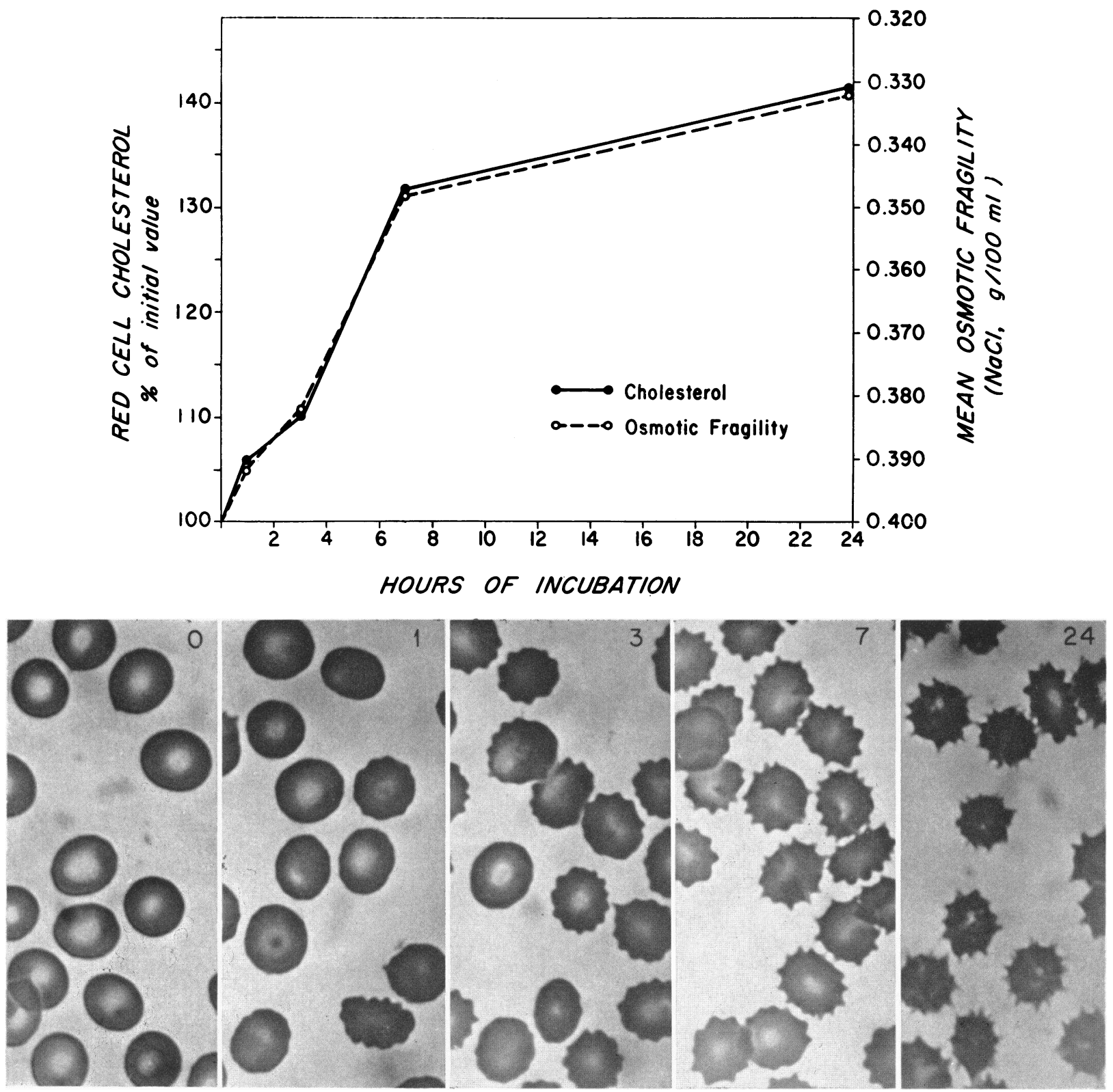

FIgURE 1 Effects of spur serum on normal red cells. Normal red cells (top) incubated in serum from patient 1 progressively gained cholesterol, became resistant to osmotic lysis, and acquired thorny membrane projections. Photomicrographs (bottom) are of Wright's stained smears prepared at the time intervals noted in hours. $\times 1000$. There was no change in the cholesterol content, osmotic fragility, or morphology of these normal cells during their parallel incubation in heated autologous serum. 
$1.012-1.024,1.024-1.042,1.042-1.063$, and 1.063-1.21. These fractions were dialyzed against Hank's balanced salt solution and adjusted by dilution with Hank's to an equivalent concentration of free cholesterol. Normal red cells were incubated at a cell concentration of $5 \%$ in Hank's balanced salt solution containing the various fractions added in an amount which would provide free cholesterol at a concentration of $25 \mu \mathrm{g} / \mathrm{ml}$ of cell suspension. From the data presented in Fig. 2, this amount of cholesterol was less than that which would produce the maximal change in red cell cholesterol. There was no significant difference in the quantity of cholesterol acquired by normal red cells incubated in these various fractions, the acquisition of cholesterol varying between 16 and $22 \%$. Spicules were induced in normal red cells by all of these fractions but not by the lipoprotein-free infranatant obtained at density 1.21 .

To determine whether all of the free cholesterol of spur serum was available for transfer to normal red cells or if only a portion of it was, a sample of spur serum was incubated sequentially with three aliquots of normal red cells (Table V). After the first incubation, the serum free cholesterol concentration was decreased by $22 \%$. An additional decrease of $12 \%$ occurred during the second incubation and $4 \%$ during the third. Thus. it appears that only a portion of the free cholesterol in spur serum can be transferred to normal red cells: in

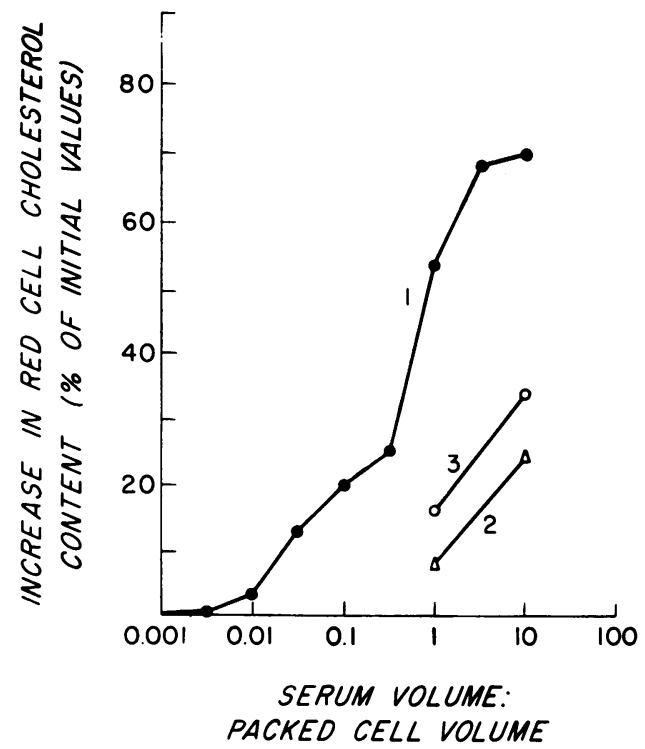

Figure 2 Effect of the relative quantities of spur serum and normal red cells on the transfer of cholesterol from serum to cells. Normal red cells were incubated for $24 \mathrm{hr}$ at a cell concentration of $5 \%$ in Hank's balanced salt solution containing serum from spur cell patients 1,2 , and 3 , the volume of which relative to the volume of cells is designated on the abscissa.
TABLE VI

Effect of Normal Serum on the Lipid Content and Osmotic Fragility of Spur Cells

\begin{tabular}{|c|c|c|c|}
\hline & $\begin{array}{l}\text { Choles- } \\
\text { terol }\end{array}$ & $\begin{array}{c}\text { Lipid } \\
\text { phosphorus }\end{array}$ & $\begin{array}{c}\text { Mean } \\
\text { osmotic } \\
\text { fragility } \\
\mathrm{NaCl}\end{array}$ \\
\hline & $\begin{array}{l}\mu g / 10^{8} \\
\text { cells }\end{array}$ & $\begin{array}{l}\mu g / 10^{8} \\
\text { cells }\end{array}$ & $\mathrm{g} / 100 \mathrm{ml}$ \\
\hline \multicolumn{4}{|l|}{ Cells from patient 1} \\
\hline Initial values & 22.30 & 1.241 & 0.416 \\
\hline $\begin{array}{l}\text { After incubation in } \\
\text { autologous serum }\end{array}$ & 22.14 & 1.247 & 0.426 \\
\hline $\begin{array}{l}\text { After incubation in } \\
\text { normal heated serum }\end{array}$ & 13.27 & 1.26 .3 & 0.657 \\
\hline \multicolumn{4}{|l|}{ Cells from patient 2} \\
\hline Initial values & 20.11 & 1.401 & 0.400 \\
\hline $\begin{array}{l}\text { After incubation in } \\
\text { autologous serum }\end{array}$ & 19.17 & 1.403 & 0.410 \\
\hline $\begin{array}{l}\text { After incubation in } \\
\text { normal heated serum }\end{array}$ & 14.62 & 1.366 & 0.488 \\
\hline \multicolumn{4}{|l|}{ Cells from patient 3} \\
\hline Initial values & 19.11 & 1.275 & 0.405 \\
\hline $\begin{array}{l}\text { After incubation in } \\
\text { autologous serum }\end{array}$ & 19.24 & 1.289 & 0.403 \\
\hline $\begin{array}{l}\text { After incubation in } \\
\text { normal heated serum }\end{array}$ & 14.33 & 1.317 & 0.560 \\
\hline
\end{tabular}

the serum from patient 1 this accounted for $38 \%$ of the serum free cholesterol.

The transfer of free cholesterol from spur serum to normal red cells was inhibited by the addition of normal serum, whether fresh or previously heated to $56^{\circ} \mathrm{C}$. To quantitate this, normal red cells were incubated with a volume of serum from patient 1 which would produce a submaximal $(30 \%)$ increase in red cell cholesterol. While keeping the total volume of the incubation constant, heated normal serum was added. The transfer of cholesterol to normal red cells was decreased by $10 \%$ when the volume of normal serum added was equal to the volume of spur serum, $43 \%$ when the volume of normal serum was 2 -fold the volume of spur serum, and $100 \%$ when the volume of normal serum was 10 -fold that of spur serum. Thus, normal serum lipoproteins are also able to serve as repositories for the excess free cholesterol in spur sera. Since there was free cholesterol in the normal serum which was added, it is of note that the least transfer of cholesterol from serum to cell occurred when the free cholesterol content of the entire medium (normal serum + spur serum) was greatest.

The effect of normal serum on spur cells. The red cells from all three patients with spur cells lost cholesterol when incubated in heated normal serum (Table VI). They also lost their thorny membrane projections and became spheroidal in appearance and osmotically fragile. However, no change occurred in their content 
of phospholipid. Parallel incubations of spur cells in autologous serum resulted in no significant changes in morphology, lipid content, or osmotic fragility.

This loss of cholesterol from spur cells into heated normal serum was related to the ratio of serum volume to packed cell volume during incubation (Fig. 3). With increasing quantities of serum, there was a progressive loss of cholesterol from the red cells of patient 1 . When approximately $50 \%$ of the cell cholesterol was lost, the spheroidicity which resulted caused hemolysis in isotonic solutions. These cells also lost cholesterol when incubated in the density 1.063 infranatant of normal serum or in normal serum which contained only lipoproteins of density 1.063 . However, they did not lose cholesterol when incubated in Hank's solution with no added serum.

The cholesterol lost from spur cells into heated normal serum was quantitatively recovered, primarily as free cholesterol (Table VII). To test the affinity with which this cholesterol was bound to serum lipoproteins. the supernatant obtained after incubation of spur cells in normal serum was incubated with normal red cells. In two such experiments, the cholesterol content of normal red cells was increased by 28.7 and $21.8 \%$, respectively.

Studies in vivo. The fact that normal red cells incubated in spur sera were resistant to osmotic lysis whereas the osmotic fragility of spur cells themselves fell within the normal range appeared inconsistent. To study this

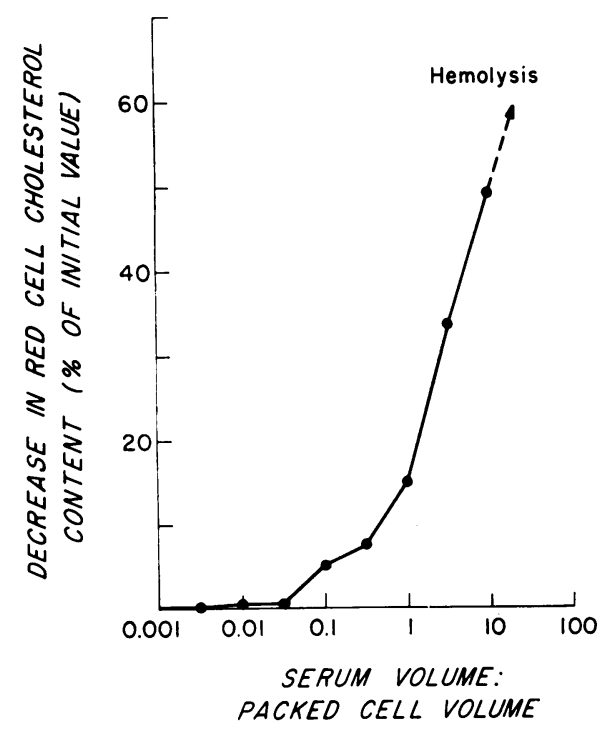

FIGURE 3 Effect of the relative quantities of normal serum and spur cells on the transfer of cholesterol from cells to serum. Spur cells from patient 1 were incubated for $24 \mathrm{hr}$ at a cell concentration of $5 \%$ in Hank's balanced salt solution containing heated normal serum, the volume of which relative to the volume of cells is designated on the abscissa.
TABLE VII

Alterations in the Lipid Content of Normal Heated Serum after Incubation with Spur Cells

\begin{tabular}{lccc}
\hline & \multicolumn{2}{c}{ Lipid content } & \\
\cline { 2 - 3 } & $\begin{array}{c}\text { Before } \\
\text { incuba- } \\
\text { tion }\end{array}$ & $\begin{array}{c}\text { After } \\
\text { incuba- } \\
\text { tion }\end{array}$ & Difference \\
\hline Cholesterol & $\mu g / 3 \mathrm{ml}$ cell suspension & \\
$\quad$ Serum, free & 546 & 920 & +374 \\
Serum, total & 2788 & 3288 & +500 \\
Red cell & 2056 & 1528 & -528 \\
Phospholipid & & & \\
$\quad$ Serum & 1512 & 1512 & 0 \\
Red cell & 2630 & 2558 & -72 \\
\hline
\end{tabular}

* Red cells from patient 1 were suspended in Hank's solution at a cell concentration of $80 \%$ and brought to final cell concentration of $35 \%$ by the addition of normal heated serum. Serum values represent the lipid content of the entire supernatant (serum plus a small amount of buffer). Cholesterol was lost from spur cells and was recovered in serum primarily as free cholesterol. No significant change occurred in the phospholipid content of either red cells or serum.

in vivo, the osmotic fragility of normal red cells labeled with ${ }^{51} \mathrm{Cr}$ and transfused into patient 1 was measured (Fig. 4). During the first $7 \mathrm{hr}$ after transfusion. the normal red cells became progressivly more resistant to osmotic lysis, as had been observed in vitro during the incubation of normal red cells in spur sera. Between the 7th and 23rd hr their mean osmotic resistance further increased while a portion of the red cells became more fragile than they had been at seven hr. Over the course of the subsequent 7 days, the resistance of the transfused cells to osmotic lysis progressively decreased. The ${ }^{51} \mathrm{Cr}$ half-survival of these cells was 8 days. The ${ }^{51} \mathrm{Cr}$ half-survival of the patient's red cell autotransfused was 6 days. Splenic sequestration predominated in both instances.

If the shift to a more fragile cell population between days 1 and 8 had been due to the destruction of that half of the cell population which was most resistant to osmotic lysis, the osmotic fragility of the remaining cells should have been similar to the osmotic fragility of the more fragile half of the cell population at $23 \mathrm{hr}$. i.e., it should have had a mean osmotic fragility of 0.35 gm. $\mathrm{NaCl} / 100 \mathrm{ml}$. However the mean osmotic fragility on day 8 was 0.41 . Thus, the shift to a more fragile cell population cannot be accounted for by the destruction of the most resistant cells. Rather, these data imply that factors unique to the circulation in vivo caused changes in these red cells such that they became more osmotically fragile and, in addition, experienced a marked shortening of survival. 
To study in vitro the influence of the microcirculation on red cell in vivo, red cell transit through $5 \mu$ Millipore filters was measured. After incubation in serum from patient 1 , the filterability of normal red cells was reduced $40.5 \%$, whereas after their parallel incubation in heated normal serum their filterability was decreased $4.5 \%$. Thus, the change in cell shape induced by spur serum diminished the cell's deformability and inhibited its passage through channels in vitro which correspond in size to the channels which red cells must traverse in vitro (31).

The relationship between spur cells and target cells. The content of cholesterol is also increased in red cells from patients with obstructive jaundice $(26,32,33)$. Red cells in this condition are not spiculated, but rather are targeted in appearance and resistant to osmotic lysis (26). In nine patients with obstructive jaundice studied in this laboratory, there was a $42 \%$ increase in red cell cholesterol, a $17 \%$ increase in phospholipid, and a $21 \%$ increase in the cholesterol:phospholipid ratio (34). Incubation studies have demonstrated that sera from patients with obstructive jaundice transfer cholesterol to normal cells (26); however, these red cells do not become spiculated in vitro. Normal red cells which had undergone a $20 \%$ increase in cholesterol content after incubation in obstructive jaundice serum had a normal filterability through $5 \mu$ Millipore filters.

To study whether lipid addition to red cells in obstructive jaundice differs from the process in liver disease with spur cells, measurements were made of the effect of serum from spur cell patient 1 on the cholesterol content of red cells obtained from patients with obstructive jaundice, from spur cell patients 2 and 3, and from normal subjects (Table VIII). Normal red cells incubated in this serum acquired an increment in cholesterol which averaged $8.77 \mu \mathrm{g} / 10^{8}$ cells and, thus, a cholesterol content similar to that of the red cells obtained from patient 1 . Red cells from patients with obstructive jaundice acquired a similar increment in cholesterol. However, since their lipid content was greater than normal before incubation, their final cholesterol content exceeded that of normal cells incubated in the same serum. The content of cholesterol in the red cells of spur cell patients 2 and 3 was also initially elevated. When these spur cells were incubated in serum from patient 1 , who was more severely affected, they attained a final cholesterol content similar to that of the red cells of patient 1 . Their absolute increment in cholesterol content, therefore, was strikingly less than the

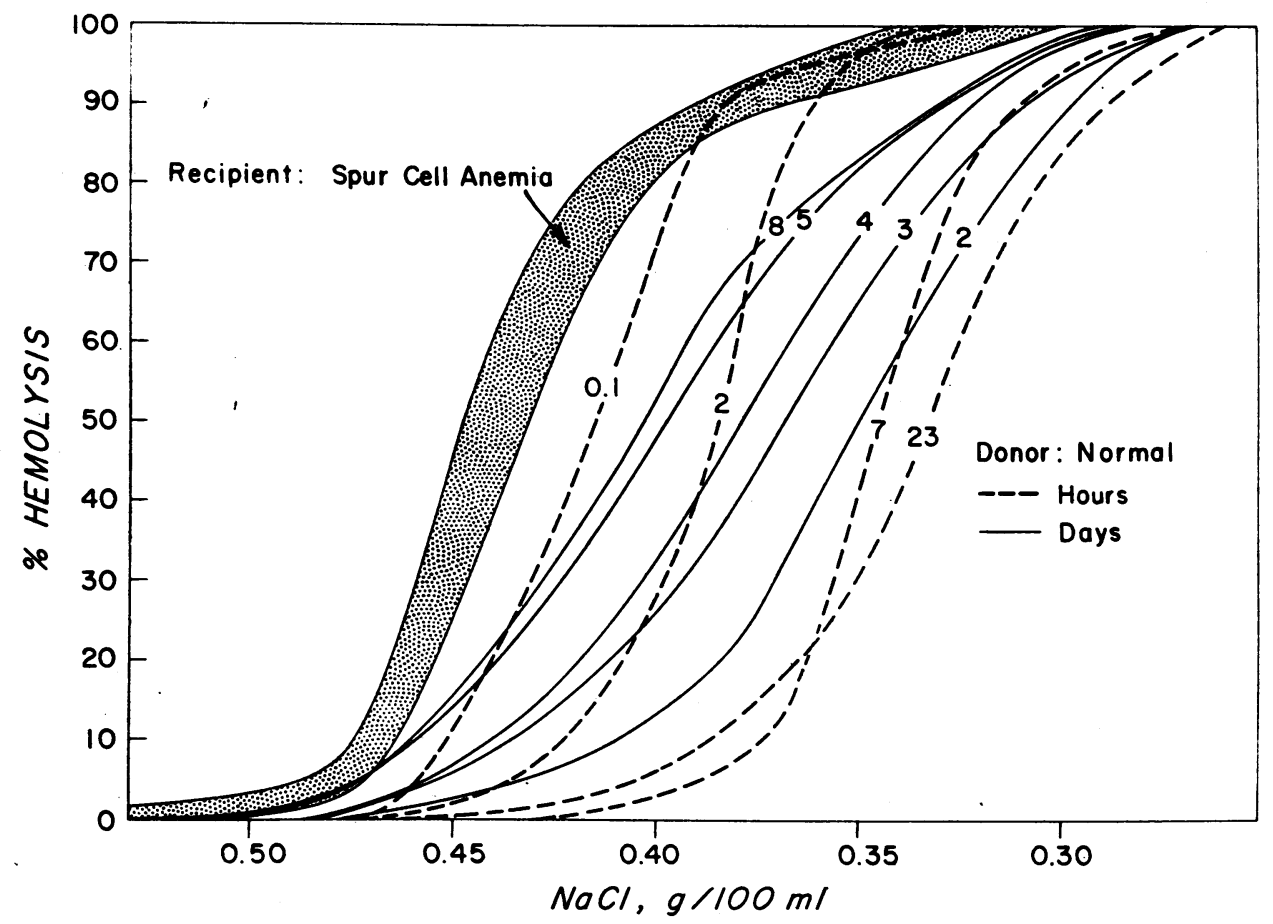

Figure 4 Osmotic fragility of normal ${ }^{\circ} \mathrm{Cr}$-labeled red cells after transfusion into a patient. with spur cells. The osmotic fragility of the transfused cells was measured by ${ }^{51} \mathrm{Cr}$ released and of the recipient's own cells by hemoglobin released during lysis. The transfused cells became resistant to osmotic lysis during the first $23 \mathrm{hr}$ but thereafter they became progressively more osmotically fragile. 
TABLE VIII

The Effect of Serum from Patient 1 on the Cholesterol Content of Various Red Cells

\begin{tabular}{|c|c|c|c|}
\hline \multirow[b]{2}{*}{ Cell donor } & \multicolumn{2}{|c|}{ Red cell cholesterol content } & \multirow[b]{2}{*}{ Difference } \\
\hline & $\begin{array}{c}\text { Before } \\
\text { incubation }\end{array}$ & $\begin{array}{c}\text { After } \\
\text { incubation }\end{array}$ & \\
\hline & \multicolumn{2}{|c|}{$\mu g / 10^{8}$ cells } & \\
\hline Normal & 14.37 & 22.02 & +7.65 \\
\hline Normal & 14.28 & 22.71 & +8.43 \\
\hline Normal & 13.64 & 23.45 & +9.81 \\
\hline Normal & 13.72 & 22.45 & +8.72 \\
\hline Normal & 13.66 & 22.62 & +8.96 \\
\hline Normal & 13.42 & 21.62 & +8.20 \\
\hline Normal & 13.10 & 22.74 & +9.64 \\
\hline Mean & 13.74 & 22.52 & +8.77 \\
\hline Obstructive jaundice & 19.65 & 29.10 & +9.45 \\
\hline Obstructive jaundice & 19.14 & 25.34 & +6.20 \\
\hline Obstructive jaundice & 17.65 & 26.25 & +8.60 \\
\hline Biliary cirrhosis & 19.30 & 27.50 & +8.20 \\
\hline Mean & 18.94 & 27.05 & +8.11 \\
\hline Spur cell patient 2 & 18.89 & 22.16 & +2.27 \\
\hline Spur cell patient 3 & 19.85 & 21.89 & +2.04 \\
\hline Spur cell patient 1 & 22.30 & 22.14 & -0.16 \\
\hline
\end{tabular}

uniform increase noted in the red cells from normal subjects and from patients with obstructive jaundice. Thus, it appears that the acquisition of cholesterol by spur cells differs from the acquisition of cholesterol in obstructive jaundice and that the two are additive.

To test whether the red cell membrane is unique in its ability to acquire cholesterol from spur serum or whether other membranes behave in a similar fashion, the effect of spur plasma on normal platelets was measured. After incubation in plasma from patient 1 , the cholesterol content of normal platelets was increased by $45 \%$ (from an initial value of 9.31 to $13.50 \mu \mathrm{g} / 10^{8}$ platelets), whereas no change occurred during incubation in heated normal plasma. The platelet content of lipid phosphorus (which was $8.68 \mu \mathrm{g} / 10^{\circ}$ platelets) did not change under either condition of incubation.

\section{DISCUSSION}

Membrane changes in vitro and in vivo. Normal red cells acquired membrane cholesterol in spur serum. This addition of cholesterol to the cell membrane was associated with an increase in its surface area, reflected by an increased resistance to osmotic lysis. Closely correlated with (but not necessarily causally related to) these changes in cholesterol content and osmotic resistance was a change in red cell morphology, illustrated in Fig. 1. Similar changes in osmotic fragility (Fig. 4) and morphology $(2,3)$ were also demonstrated in vivo. However, after initially becoming osmotically resistant in vivo, normal red cells transfused into a spur cell patient slowly and progressively became more osmotically fragile (Fig. 4). Thus, it appears that a phenomenon unique to the circulation acted upon the red cell membrane to decrease its surface area. This finding contrasts with the persistence of the osmotic resistance acquired by normal red cells after transfusion into patients with obstructive jaundice (26). Possibly the impaired filterability of spiculated red cells caused them to lose pieces of membrane, even entire spicules, as they traversed small orifices. Hemoglobin-poor fragments resembling spicules were observed in smears of blood from patient 1. A similar loss of membrane fragments has been suggested in the etiology of other hemolytic anemias (35). Fragmentation may also explain the change in the morphology of spicules from a regular, thorny appearance in vitro to an irregular and often bizarre appearance in vivo, a difference previously commented upon by Grahn, Dietz, Stefani, and Donnelly (5). In a sense, the acquisition of cholesterol in vivo was protective to these red cells, permitting them a normal surface area despite the loss of portions of their membranes. However, when their excess, loosely bound cholesterol was eluted into heated normal serum, their underlying deficiency in surface area was apparent as these spur cells became both spherocytic in appearance and osmotically fragile.

The lipid content of red cells with spicules. Red cells with thorny membrane projections in patients with liver disease are appropriately termed spur cells to distinguish them from spiculated cells occurring in other conditions. The hallmark of spur cells is their markedly increased cholesterol: phospholipid ratio, as seen in the patients reported here as well as previously $(2,3)$. Although it has been demonstrated that sterols other than cholesterol can replace cholesterol in the red cell membrane (36), the sterol present both in the red cells of patient 1 and in normal red cells incubated in serum from patient 1 was shown to be cholesterol. Patients with liver disease of the obstructive variety also have an increased red cell content of cholesterol $(26,32,33)$. However, we have not encountered any patient with obstructive jaundice in whom the cholesterol: phospholipid ratio of red cells was increased to the striking degree seen in the patients with spur cells.

The formation of spicules by normal red cells in vitro has been reviewed by Ponder (37) and, more recently, by Deuticke (38). Substances which induce spicules are generally amphiphilic and anionic or nonionized (38). However, such agents usually induce spicules within seconds, in contrast to the slow time course depicted in Fig. 1, as also noted by others $(7,8)$. Those serum fractions obtained by density centrifugation which contained free cholesterol were able to induce these morphologic changes; however, the lipoprotein-free (density 1.21 infranatant) fraction of spur serum was not. Similarly, only the lipoprotein-rich portion of spur se- 
rum obtained by Sephadex column fractionation was able to induce spicules in normal cells (8). Grahn et al. (5) found that those ammonium sulfate fractions of spur serum which were richest in albumin were best able to induce spicules. However, fractions richest in albumin are also richest in both alpha- and beta-lipoprotein. Spiculated, cholesterol-loaded red cells have also been described in three experimental animals: rabbits fed cholesterol $(39,40)$, rats fed orotic acid (41), and Rhesus monkeys fed lithocholic acid (42).

The qualitative relationship between spicules and cholesterol cited above does not provide proof that cholesterol acquisition itself causes spicules. Moreover, two lines of evidence cast doubt on the quantitative relationship between these two phenomena. First, the per cent of spiculated red cells seen on Wright's stained smears varies considerably from day to day, while red cell lipid content varies little. Gottfried and Kayden (43) found that $1 \mathrm{yr}$ before her inclusion in the present study, and at a time when spicule cells were present but were few in number, the red cell lipids in patient 3 were the same as at the time of the present study. Second, recent studies of spur cells in Rhesus monkeys fed lithocholic acid (42) have demonstrated spicule formation in vivo several days before a measurable increase in red cell cholesterol occurred.

The relationship between spur and target cells. Both target cells and spur cells have an increased membrane content of cholesterol, and the sera from patients with both types of red cells have a deficiency of lecithin: cholesterol acyltransferase. Cholesterol addition in obstructive jaundice has been related to an elevation of the serum concentration of bile salts (23). Serum bile salt concentrations were also elevated in the patients with spur cells, the total levels exceeding those usually seen in obstructive jaundice $(23,26,44)$. As noted previously (44), the elevation of serum bile salts in patients with obstructive jaundice consists primarily of cholic acid, while patients with hepatocellular disease accumulate chenodeoxycholic acid and its toxic degradation product, lithocholic acid (30). The patients reported here with spur cells had striking elevations of chenodeoxycholic acid and easily measurable levels of lithocholic acid (Table III). The possible importance of lithocholic acid in this syndrome is emphasized by the recent finding from this laboratory that Rhesus monkeys fed a diet containing lithocholic acid develop spur red cells and a syndrome similar to that described here in patients (42).

Red cell-serum free cholesterol balance. Red cell and serum free cholesterol exist as a single pool $(45,46)$. A decrease in this pool occurs when serum free cholesterol is esterified during incubation in vitro, and this results in a decline of red cell cholesterol as well (47).
In contrast, an increase in the serum concentration of free cholesterol, as occurs in familial hypercholesterolemia, is not associated with a change in the cholesterol content of red cells in vivo (48) or in vitro (26). However, while esterification in vitro results in a decrease in the serum free cholesterol content without a change in the number of lipoprotein "binding sites," in hypercholesterolemia there is apparently an increase in both the serum free cholesterol content and the number of lipoprotein sites available to bind it. Thus, it is not the absolute quantity of free cholesterol in serum which determines red cell cholesterol, but, rather, the relative affinity of the serum and cell binding sites for this free cholesterol. This concept is consistent with the lack of correlation between the serum free cholesterol concentration of the three spur cell patients and the amount of cholesterol their sera transferred to normal red cells. It is supported by the fact that although dilution of spur serum in normal serum resulted in a higher free cholesterol concentration than dilution in buffer, more cholesterol was transferred to normal red cells when dilution was in buffer.

The total cholesterol concentrations in serum have varied among the spur cell patients reported here, as well as previously. However, in all cases in which the values are given, free cholesterol accounted for a greater than normal per cent of the total serum cholesterol. The data presented above indicate that a portion of the free cholesterol in the serum of patients with spur cells was "loosely bound" to serum lipoproteins. This cholesterol readily transferred to other binding sites, such as red cells, platelets, or the lipoproteins of normal serum. In patient 1 , this loosely bound fraction accounted for $\frac{1}{3}$ of the serum free cholesterol.

The excess cholesterol present in spur cells was also loosely bound, and it moved from these abnormal cells to normal serum lipoproteins, elevating the free cholesterol concentration of normal serum by as much as $25 \mathrm{mg} / 100 \mathrm{ml}$. This loss of membrane cholesterol was associated with a decrease in the surface area of spur cells, reflected by an increase in their osmotic fragility. The cholesterol lost into serum remained loosely bound and readily transferred to normal red cells. Movements of cholesterol from one binding site of low affinity to another were accomplished in vitro by manipulating the relative quantities of serum and cells in the incubation mixtures, and they occurred without concomitant movements of phospholipid. Although the cholesterol transferred to red cells in this fashion remained loosely bound, i.e. it was easily removed by an available binding site of higher affinity, it appears that it was not merely adsorbed to the membrane. Rather, the data are consistent with the concept that cholesterol entered into membrane lipoproteins increasing their size, and this 
was reflected by an increase in the surface area of the red cell membrane and the resistance of the cell to osmotic lysis.

\section{ACKNOWLEDGMENTS}

The author is grateful to Miss J. Nordberg and Miss C. Buzas for their technical assistance and to Miss T. Steinberg for her secretarial assistance. Blood from patient 2 was kindly made available by Doctors $\mathrm{J}$. McBride and $\mathrm{H}$. Jacob, St. Elizabeth Hospital, Brighton, Mass., and from patient 3 by Doctors R. Silber and H. Kayden, New York University Hospital, New York.

These studies were supported in part by grants HE-07652, T1-AM-5391, and Fr-76 and Research Fellowship grant 1-F3-AM38,345 from the National Institutes of Health.

\section{REFERENCES}

1. Cooper, R. A., and J. H. Jandl. 1968. Modification of red cell survival induced by membrane cholesterol. Clin. Res. 16: 301. (Abstr.)

2. Smith, J. A., E. T. Lonergan, and K. Sterling. 1964. Spur-cell anemia. Hemolytic anemia with red cells resembling acanthocytes in alcoholic cirrhosis. N. Engl. J. Med. 271: 396.

3. Silber, R., E. Amorosi, J. Lhowe, and H. J. Kayden. 1966. Spur-shaped erythrocytes in Laennec's cirrhosis. N. Engl. J. Med. 275 : 639.

4. Douglass, C. C., M. S. McCall, and E. P. Frenkel. 1968. The acanthocyte in cirrhosis with hemolytic anemia. Ann. Intern. Med. 68: 391.

5. Grahn, E. P., A. A. Dietz, S. S. Stefani, and W. J. Donnelly. 1968. Burr cells, hemolytic anemia, and cirrhosis. Amer. J. Med. 45: 78.

6. Goldstein, B. D., C. McFadden, and J. S. O'Brein. 1968. $\mathrm{RBC}$ membrane in spur cell abnormality associated with alcoholics. Clin. Res. 16: 303. (Abstr.)

7. Tchernia, G., J. Navarro, R. Becart, and A. Casasoprana. 1968. Anemie hemolytique avec acanthocytose et dyslipidemie au cours de deux hepatites neonatales. Arch. Fr. Pediat. 25 : 729.

8. Martinez-Maldonado, M. 1968. Role of lipoproteins in the formation of spur cell anaemia. J. Clin. Pathol. (London). 21: 620.

9. Ways, P., C. F. Reed, and D. J. Hanahan. 1963. Redcell and plasma lipids in acanthocytosis. J. Clin. Invest. 42: 1248.

10. Phillips, G. B. 1962. Quantitative chromatographic analysis of plasma and red cell lipids in patients with acanthocytosis. J. Lab. Clin. Med. 59: 357.

11. Emerson, C. P., S. C. Shen, T. H. Ham, E. M. Fleming, and W. B. Castle. 1956. Studies on the destruction of red blood cells. IX. Quantitative methods for determining the osmotic and mechanical fragility of red cells in the peripheral blood and splenic pulp; the mechanism of increased hemolysis in hereditary spherocytosis (congenital hemolytic jaundice) as related to the function of spleen. Arch. Intern. Med. 97: 1.

12. Rose, H. G., and M. Oklander. 1965. Improved procedure for the extraction of lipids from human erythrocytes. J. Lipid Res. 6: 428.

13. Zlatkis, A., B. Zak, and A. J. Boyle. 1953. A new method for the direct determination of serum cholesterol. I. Lab. Clin. Med. 41: 486.
14. Bartlett, G. R. 1959. Phosphorus assay in column chromatography. J. Biol. Chem. 234: 466.

15. Smith, L. L., W. S. Matthews, J. C. Price, R. C. Bachmann, and B. Reynolds. 1967. Thin-layer chromatographic examination of cholesterol autoxidation. J. Chromatogr. $27: 187$.

16. Miettinen, T. A., E. H. Ahrens, Jr., and S. M. Grundy. 1965. Quantitative isolation and gas-liquid chromatographic analysis of total dietary and fecal neutral steroids. J. Lipid Res. 6: 411.

17. Dodge, J. T., C. Mitchell, and D. J. Hanahan. 1963. The preparation and chemical characteristics of hemoglobin-free ghosts of human erythrocytes. Arch. Biochem. Biophys. 100: 119.

18. Jandl, J. H., R. L. Simmons, and W. B. Castle. 1961 Red cell filtration and the pathogenesis of certain hemolytic anemias. Blood. 18: 133.

19. Brown, H. H., A. Zlatkis, B. Zak, and A. J. Boyle. 1954. Rapid procedure for the determination of free serum cholesterol. Anal. Chem. 26: 397.

20. Havel, R. J., H. A. Eder, and J. H. Bragdon. 1955. The distribution and chemical composition of ultracentrifugally separated lipoproteins in human serum. J. Clin. Invest. 34: 1345.

21. Laurell, C. B., and J. E. Nilehn. 1965. A new type of inherited serum albumin anomaly. J. Clin. Invest. 45: 1935

22. Laurell, C. B. Quantitative estimation of proteins by electrophoresis in agarose gel containing antibodies. Anal. Biochem. 15: 45.

23. Sandberg, D. H., J. Sjövall, K. Sjövall, and D. A. Turner. 1965. Measurement of human serum bile acids by gas-liquid chromatography. J. Lipid Res. 6: 182.

24. Sperry, W. M. 1935. Cholesterol esterase in blood. $I$. Biol. Chem. 111 : 467.

25. Glomset, J. A. 1968. The plasma lecithins: cholesterol acyltransferase reaction. J. Lipid Res. 9: 155.

26. Cooper, R. A., and J. H. Jandl. 1968. Bile salts and cholesterol in the pathogenesis of target cells in obstructive jaundice. J. Clin. Invest. 47: 809.

27. Jand1, J. H., M. S. Greenberg, R. H. Yonemoto, and W. B. Castle. 1956. Clinical determination of sites of red cell sequestration in hemolytic anemias. J. Clin. Ini'est. 35: 842 .

28. Mollison, P. L. 1967. Blood transfusion in clinical medicine. Blackwell Scientific Publications, Ltd., Oxford. 4th edition. 456.

29. Jandl, J. H. 1959. Modern views of immunohematology. In Proceedings of the 7th International Congress of the International Society of Hematology, Rome. 7 September 1958. Il Pensiero Scientifico, Rome. 3.

30. Carey, J. B., Jr., and G. Williams. 1965. Lithocholic acid in human-blood serum. Science (Washington). 150: 620.

31. Björkman, S. E. 1947. The splenic circulation. Acta Med. Scand. Suppl. 191.

32. Brun, G. C. 1939. Cholesterol content of red cells in man. Acta Med. Scand. Suppl. 99.

33. Neerhout, R. C. 1968. Abnormalities of erythrocyte stromal lipids in hepatic disease. J. Lab. Clin. Med. 71: 438 .

34. Cooper, R. A., and J. H. Jandl. 1969. Physiologic and pathologic alterations of red cell lipids, membrane area, 
and shape. In 1st International Symposium on Metabolism and Membrane Permeability of Erythrocytes and Thrombocytes. E. Deutsch, E. Gerlach, and K. Moser, editors. Georg Thieme Verlag, Stuttgart. 376.

35. Weed, R. I., and C. F. Reed. 1966. Membrane alterations leading to red cell destruction. Amer. J. Med. 41: 681.

36. Bruckdorfer, K. R., J. M. Graham, and C. Green. 1968. The incorporation of steroid molecules into lecithin sols, $\beta$-lipoproteins and cellular membranes. Eur. J. Biochem. 4: 512 .

37. Ponder, E. 1948. Hemolysis and Related Phenomena. Grune \& Stratton Inc., New York.

38. Deuticke, B. 1968. Transformation and restoration of biconcave shape of human erythrocytes induced by amphiphilic agents and changes in ionic environment. Biochim. Biophys. Acta. 163: 494.

39. Silver, M. M., G. C. McMillan, and M. D. Silver. 1964 Hemolytic anaemia in cholesterol-fed rabbits. Brit. J. Haematol. 10: 271.

40. Hestorff, R., P. Ways, and S. Palmer. 1965. The pathophysiology of "cholesterol anemia" in rabbits. J. Clin. Invest. 44: 1059. (Abstr.)

41. McBride, J. A., and H. S. Jacob. 1968. Cholesterol loading of acanthocytic red cell membranes causing he- molytic anemia in experimental and genetic abetalipoproteinemia. J. Clin. Invest. 47: 67a. (Abstr.)

42. Cooper, R. A., W. H. Admirand, F. Garcia, and C. Trey. 1969. The role of lithocholic acid in the pathogenesis of spur red cells and hemolytic anemia. J. Clin. Invest. 48: 18a. (Abstr.)

43. Gottfried, E. L., and J. H. Kayden. 1969. On the role of RBC cholesterol in "spur cell" formation. Ann. N.Y. Acad. Med. (Abstr.) In press.

44. Carey, J. B., Jr. 1958. The serum trihydroxy-dihydroxy bile acid ratio in liver and biliary tract disease. $J$. Clin. Invest. 37 : 1494.

45. Hagerman, J. S., and R. G. Gould. 1951. The in vitro interchange of cholesterol between plasma and red cells. Proc. Soc. Exp. Biol. Med. 78: 329.

46. Gould, R. G., G. V. LeRoy, G. T. Okita, J. J. Kabara, P. Keegan, and D. M. Bergenstal. 1955. The use of $C^{14}$ labeled acetate to study cholesterol metabolism in man. J. Lab. Clin. Med. 46: 372.

47. Murphy, J. R. 1962. Erythrocyte metabolism. III. Relationship of energy metabolism and serum factors to the osmotic fragility following incubation. J. Lab. Clin. Med. 60: 86.

48. Neerhout, R. C. 1968. Erythrocyte stromal lipids in hyperlipemic states. J. Lab. Clin. Med. 71: 448. 